\title{
DIAGNOSTICS AND TREATMENT OF NEONATAL NECROTISING ENTEROCOLITIS IN LATVIA
}

\author{
Ilze Meldere ${ }^{1,3, \#}$, Liene Rucka ${ }^{1}$ Santa Smilga ${ }^{1}$, Zane Ābola ${ }^{2,3}$, \\ and Aigars Pētersons 2,3

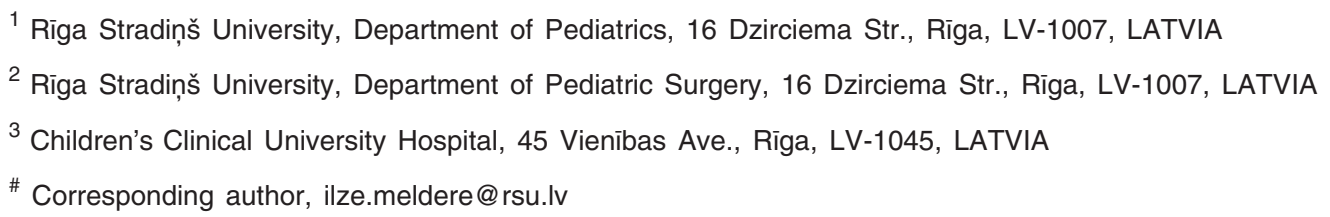

Contributed by Aigars Pētersons

\begin{abstract}
Necrotising enterocolitis (NEC) is one of the leading causes of neonatal morbidity, mortality and surgical emergencies. As the survival rate of extremely low birth weight (ELBW) infants is rising, so is the risk of NEC. The aim of this study was to compare diagnostics parameters like clinical and radiological findings and laboratory indicators and the treatment and outcome of NEC patients from 2000 till 2007 (Group 1) and from 2008 till 2016 (Group 2) treated in Neonatology Clinic (NC) of Children's Clinical University Hospital (CCUH). In the rectrospective study, 277 newborns were divided among Group I and Group II - 105 and 172 patients, respectively. There were no statistically significant differences between both study groups in mean gestational age and birth weight. In both groups the first signs of NEC appeared on average eight days after birth. Differences in the diagnostic method used in both groups were not statistically significant; specific radiological findings were seen in approximately 1/3 of the cases. There were statistically significant differences in the management of NEC and patient mortality. Conservative therapy was applied in $70.0 \%$ of patients in both study groups. Over time, peritoneal drainage (PPD) as the sole surgical treatment decreased by $6.4 \%$, but PPD with following enterostomy decreased by $8.9 \%$. In Group 2 mortality of NEC patients decreased by $17.4 \%$. Mortality among surgically treated NEC patients decreased as well, by $9.0 \%$.
\end{abstract}

Key words: neonate, preterm infant, necrotising enterocolitis, surgical management, mortality.

\section{INTRODUCTION}

Neonatal necrotising enterocolitis (NEC) is a disease that affects the gastrointestinal tract of neonates and is characterised by focal or diffuse intestinal necrosis. In $90 \%$ of cases NEC affects preterm infants, particularly those with extremely low birth weight (ELBW), i.e. weight under 1000 grams, and very low birth weight (VLBW), i.e., 1000-1500 grams (Hall et al., 2013). The incidence of NEC varies from 1 to 3 in 1000 live births and NEC affects 1 to $5 \%$ of infants in neonatal intensive care units (NICU) (Maheshwari et al., 2011). The incidence of NEC continues to increase due to more ELBW and VLBW infants being born, as more preterm infants are treated in the NICU and new technologies are being introduced. Risk factors such as immaturity of intestines due to prematurity, initiation of enteral feedings and bacterial infection play a significant role in the pathogenesis of NEC.

The diagnostics of NEC is based on clinical examination, and radiological and laboratory findings. In 1978, Dr. Martin Bell described three clinical stages of NEC, and the Bell's staging criteria have been modified various times. The criteria distinguish initial, proven, and surgical NEC. The stage of NEC depends on various clinical signs. The typical local signs of NEC are abdominal distention, abdominal wall oedema and erythema, ascites, and increased gastric residuals with or without bile, emesis, occult or grossly bloody stools. Systemic signs include lethargy, apnea, signs of septic shock, but laboratory findings show thrombocytopenia, elevated inflammatory markers (i.e. leukocytosis or leukopenia, elevated C reactive protein level, 
interleukin 6), metabolic acidosis and electrolyte imbalance. Radiography (i.e. abdominal ultrasound and abdominal Xray) plays a significant role in the diagnostics of NEC. Pathognomonic radiological findings of NEC are intestinal pneumatosis (intramural gas due to the production of gas from bacterial fermentation in the intestinal wall), fixed bowel loops, signs of ileus and pneumoperitoneum. Free fluid in the abdominal and pleural cavity, pneumoperitoneum and mass lesions can be visualised by ultrasonography.

There are two treatment options: medical or nonsurgical treatment and surgical treatment performed with additional medical treatment. Medical management includes nil per os, complete bowel rest and gastric decompression, broadspectrum antibiotics, correction of hypovolemia and acidbase imbalance, blood transfusions in case of thrombocytopenia and/or anaemia and total parenteral feeding. Absolute indications for surgical management are pneumoperitoneum and peritonitis. The surgical approach depends on the infant's health condition, the staging of NEC and intraoperative findings. Laparotomy with resection of necrotic bowel with anastomosis or creation of enterostomy are known as the traditional surgical approaches. Primary peritoneal drainage (PPD), which can be followed or not by enterostomy in ELBW infants, can be used as an alternative approach (Downard et al., 2012).

NEC is a devastating disease in the neonatal period due to its various clinical findings, aggressive and possibly fulminant course. It is one of the most common causes of neonatal morbidity, mortality and surgical emergencies (Gephard et al., 2013).

The aim of this study was to compare diagnostics parameters like clinical and radiological findings and laboratory indicators and the treatment and outcome of NEC patients from 2000 till 2007 and from 2008 till 2016.

\section{MATERIALS AND METHODS}

The Ethical Committee of Children' Clinical University Hospital approved the study protocol, which was created in accordance with the Patient Data Protection Regulation.

A retrospective study was performed from January 2000 to December 2016, which included 277 patients from the Neonatology Clinic (NC) of the Children's Clinical University Hospitals' (CCUH) diagnosed with NEC according to International Classification of Diseases 10th revision (ICD-10). All the medical records with code P77 (Necrotising enterocolitis of newborn) were analysed (ICD-10, 2016). Patients were divided into two groups: Group 1 - patients hospitalised in CCUH NC from January 2000 to December 2007 (n = 105), and Group 2 - patients hospitalised from January 2008 to December 2016 ( $\mathrm{n}=172$ ). Assessed parameters were compared between the two groups including sex, birth weight, weeks of gestation. The clinical stages of NEC of both groups were compared according to Bell's Staging Cri- teria taking into account the diagnostic parameters. The following diagnostic clinical findings were assessed; general and local abdominal symptoms, radiological ultrasound and $\mathrm{X}$-ray findings and laboratory labels (number of leukocytes and trombocytes, $\mathrm{C}$ reactive protein and interleukin 6 levels, $\mathrm{pH}$ and baseline excess (BE) levels of blood gases. The applied therapies (medical or surgical) were compared for both groups. Four surgical methods used in both groups were evaluated and compared: PPD, PPD and following enterostomy, bowel resection with the enterostomy and bowel resection with creation of primary anastomoses. In both study groups mortality was assessed and compared by birth weight and treatment management. Data were collected using Microsoft Excel 2013 and analysed with STATA/IC v.12.5. The Kruskal-Wallis $\mathrm{H}$ and Student $\mathrm{T}$ test was applied.

\section{RESULTS}

The sex distribution was similar - $137(49.5 \%)$ male and $140(50.5 \%)$ female newborns. NEC was more common in ELBW and very low birth weight (VLBW) infants in both groups - $33(32.4 \%)$ ELBW infants in Group 1 and 71 $(41.3 \%)$ in Group 2, and $34(32.4 \%)$ VLBW infants in Group 1 and $50(29.1 \%)$ - in Group 2. No statistically significant difference in mean weeks of gestation was found between Group 1 and Group 2, i.e. $29.7(\mathrm{SD}=4.4)$ and 32.7 $(\mathrm{SD}=4.4)$ weeks of gestation. The first typical signs of NEC (feeding intolerance, gastric retention, abdominal enlargement, bloody stools and general signs of sepsis) were observed in the second week of life and the mean age at the time of diagnostic was $8.7(\mathrm{SD}=8.07)$ and $7.8(\mathrm{SD}=9.01)$ days in Group 1 and Group 2, respectively. The distribution of three stages according to Bell's Staging Criteria did not differ between the two groups: in Group $1-51.4 \%, 23.8 \%$ and $24.8 \%$, in Group $2-48.3 \%, 27.8 \%$ and $23.9 \%$ (Table 1). Specific radiological findings suggesting NEC were seen in $34.3 \%$ of cases in Group 1 and $34.5 \%$ - in Group 2. As expected, $68.6 \%$ patients in Group 1 and $72.7 \%$ in Group 2 received medical management. Surgical management of NEC differed significantly in both groups. Primary peritoneal drainage (PPD) as the sole surgery was used relatively less in Group II: PPD as the sole surgical manipulation in NEC decreased by $6.4 \%$, and the use of a multi-staged operation with PPD and a following enterostomy decreased by $8.9 \%$ between the two time periods. Almost equal percentage of patients underwent intestinal resection and enterostomy formation in Group 1 and Group 2, i.e. 13.3\% and $13.4 \%$, but intestinal resection and creation of primary anastomosis was chosen only in Group 2 in $2.3 \%$ of cases (Fig. 1). A statistically significant difference was found in mortality between the two groups. The overall mortality was $44.8 \%$ in Group 1 and $27.3 \%$ in Group 2. The distribution of dead newborns by birth weight between groups did not differ significantly. In both study groups the highest mortality was in ELBW neonates, i.e., 53.2\% and 57.5\% in the two groups, respectively Fig. 2 and Fig. 3). There was a $9.0 \%$ decrease of mortality between the two time periods in 


\begin{tabular}{|c|c|c|c|c|}
\hline & & $\begin{array}{c}\text { Group 1 } \\
(\mathrm{n}=105)\end{array}$ & $\begin{array}{c}\text { Group 2 } \\
(\mathrm{n}=172)\end{array}$ & $p$ value \\
\hline \multicolumn{2}{|l|}{ Male } & $50(47.5 \%)$ & $87(52.4 \%)$ & NS \\
\hline \multicolumn{2}{|l|}{ Weeks of gestation (SD) } & $29.7(+/-4.4)$ & $32,7(+/-4.4)$ & NS \\
\hline \multicolumn{2}{|l|}{ Birth weight, grams (SD) } & $2,1(+/-1.0)$ & $1.9(+/-1.0)$ & NS \\
\hline \multicolumn{2}{|c|}{ First clinical signs of NEC, days of life (SD) } & $8.7(+/-8.1)$ & $7.8(+/-9.0)$ & NS \\
\hline \multirow[t]{4}{*}{ X-ray and US abdominal findings } & No imaging done, $\%$ & 37.1 & 32.8 & NS \\
\hline & Nonspecific, $\%$ & 28.6 & 31.7 & \\
\hline & Intestinal pneumatosis, $\%$ & 16.2 & 19.3 & \\
\hline & Pneumoperitoneum, \% & 18.1 & 15.2 & \\
\hline \multirow[t]{2}{*}{ Bell's staging } & $\mathrm{I}, \%$ & 51.4 & 48.3 & NS \\
\hline & II, \% & 23.8 & 27.3 & \\
\hline \multicolumn{2}{|l|}{ Mortality } & $47(44.8 \%)$ & $47(27.3 \%)$ & 0.003 \\
\hline
\end{tabular}

SD, standard deviation; NEC, necrotising enterocolitis; NS, not significant
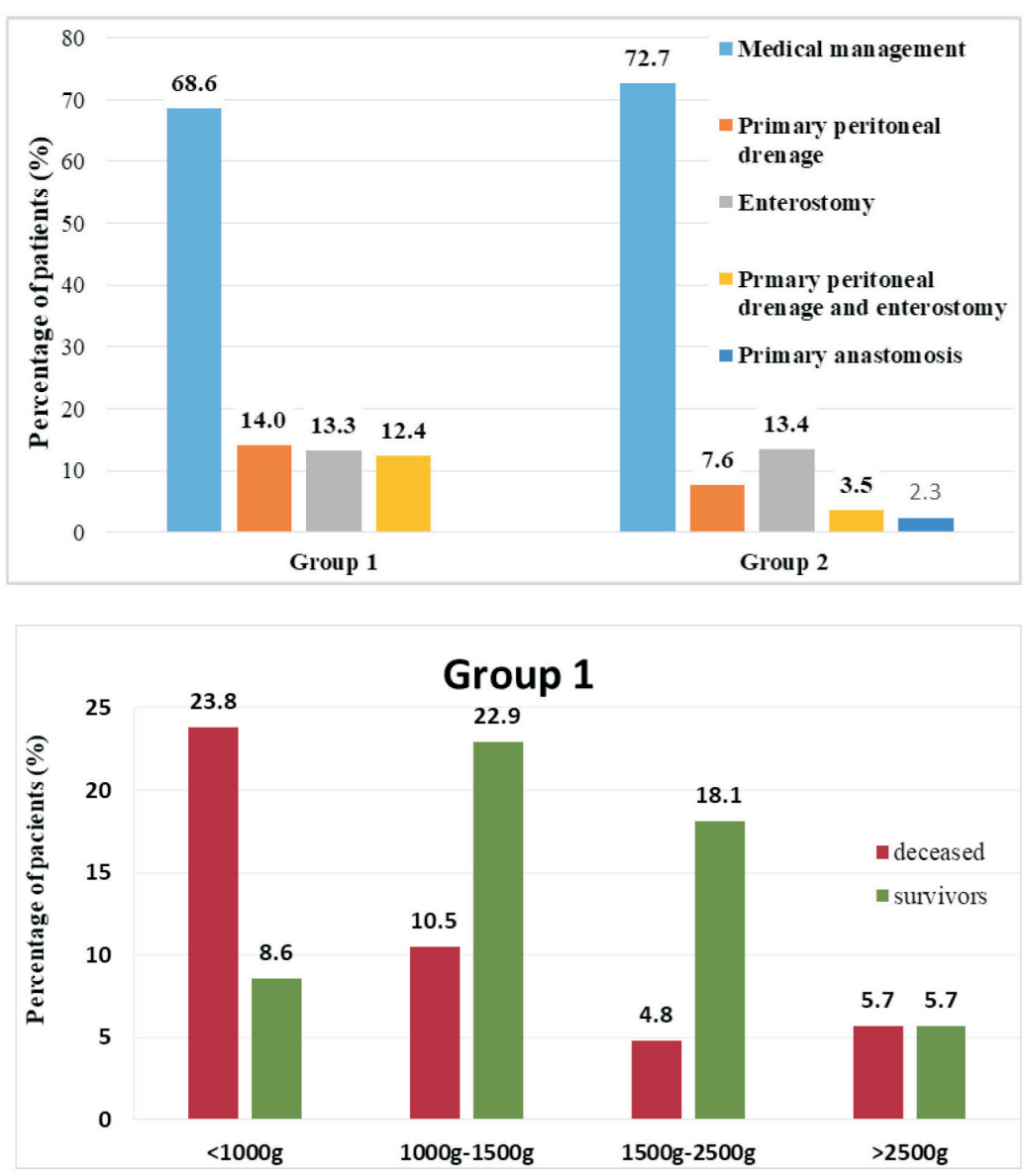

Fig. 1. Treatment used in cases of necrotising enterocolitis in both study groups $(p=0.005)$. the group of patients treated surgically - the rate of mortality in Group 1 was $20 \%$, but in Group $2-11 \%$. There is a very variable patient mortality over the years (Fig. 4).

\section{DISCUSSION}

There are approximately 20000 live births each year in Latvia, the number of births in the last 17 years has not changed significantly. In this time period there were 361 798 live births in Latvia and about $6 \%$ of them were premature births. The incidence of NEC in Latvia has been variable, i.e. from 0.2 to 1.6 per 1000 live births (Fig. 5), which is equivalent to data from other countries -0.76 to 0.98 per 1000 live births in North America, 0.5 to 5 per 1000 live births in United Kingdom, and 1.8 per 1000 live births in Canada (Shnabl 2008; Hall, 2013; Gillfilan 2017). Each 

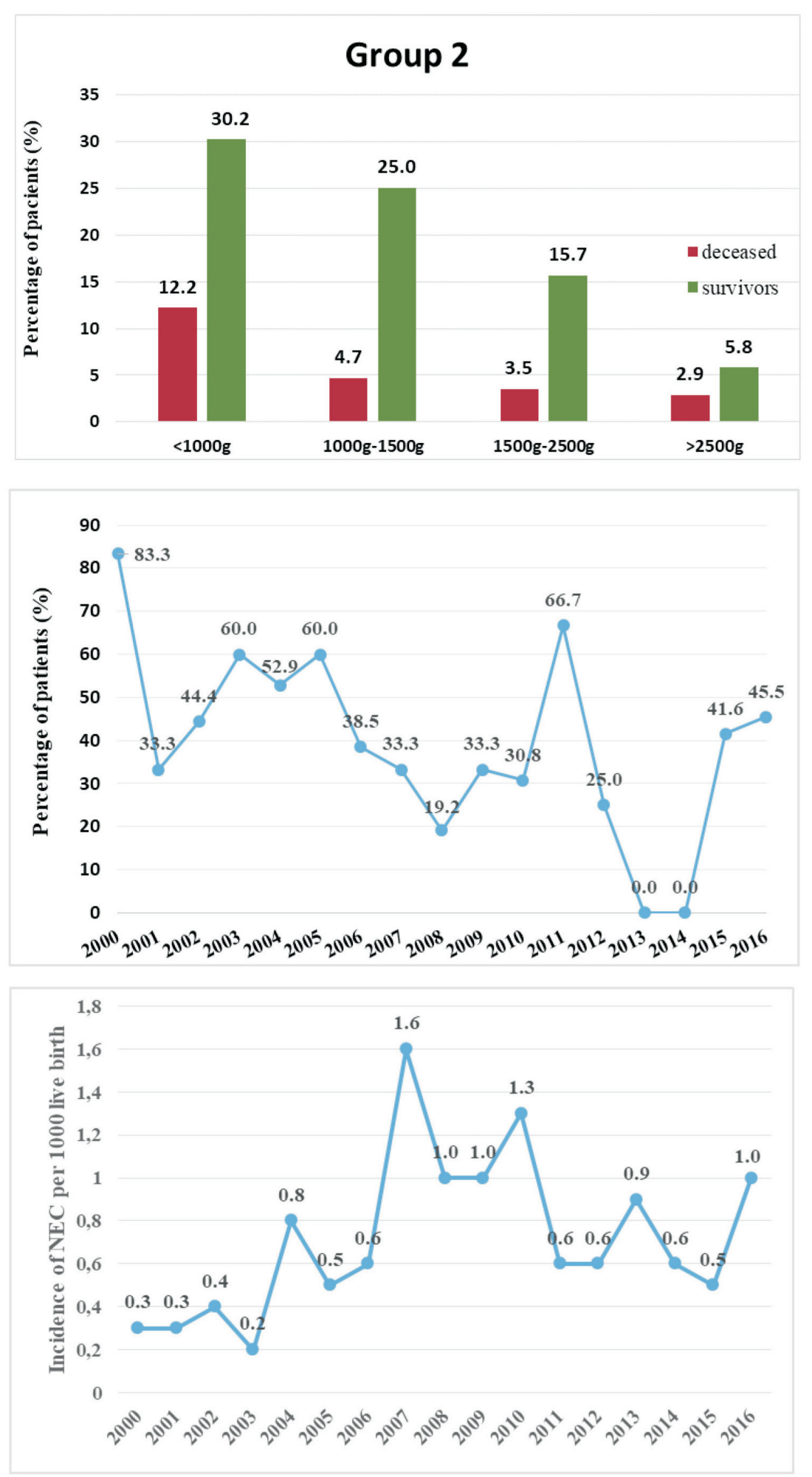

Fig. 3. Mortality and survival of patients with necrotisiting enterocolitis in Group 2 depending on their birth weight $(p=0.058)$.

Fig. 4. The mortality (\%) of newborns with necrotisiting enterocolitis. year there are 5 to 39 new cases of NEC in CCUH NC. In Latvia all NEC patients from regional perinatal centres are transported to CCUH according to guidelines for the treatment and care of newborn with NEC. During the time period from January 2000 to December 2016, there were 19240 patients in CCUH NC and $1.4 \%$ of these patients were diagnosed with NEC, which is similar as in NICUs in other countries, i.e. 2 to $5 \%$ (Gupta and Paria, 2016). The variable incidence of NEC during these years suggests that there might be diagnostic problems or the diagnosis of NEC might have different interpretations due to lack of specific markers of NEC.

In the past few years, there have been a lot of discussions regarding the definition of NEC. It has been noted that the lack of specific criteria results in misleading statistics of NEC in different NICUs, and therefore when using the Bell's Staging Criteria, all the risk factors should be take in consideration (Gupta and Paria 2016; Gephard et al., 2017; Neu et Pammi, 2017). In most of the cases in premature in- 
fants the onset of NEC is in the second or third week of life (Maheshwari et al., 2011), although in $25 \%$ of cases the onset can be even after the age of one month (Clark and Munchi, 2014). In this study most of the patients developed first clinical signs of NEC after the first week of life, when the risk factors associated with pathogenesis of NEC, i.e. immaturity of intestines due to prematurity, initiation of enteral feedings, the type of enteral feedings, bacterial colonisation of the gastrointestinal tract and possible bacterial infection are manifested (Guner et al., 2008). The interaction of risk factors leads to increased intestinal wall permeability, increased epithelial cell apoptosis of intestinal mucosa and activation of inflammatory marker cascade.

Although NEC usually affects premature infants, it can also affect infants born in term. Approximately $11 \%$ of all the NEC patients in CCUH NC were term infants with a birth weight of more than 2500 grams, which was similar to data in the literature. There are several risk factors of NEC for term infants, such as asphyxia during labour, respiratory distress, anaesthesia used during caesarean section, various prenatal factors and other underlying conditions, e.g. congenital heart disease, which causes hypoperfusion and hypoxia in gastrointestinal tract (Gephard et al., 2013; Gordon et al., 2017; Maheshwari et al., 2017).

As our rectospective study showed, in most cases $(65.0 \%)$ NEC was diagnosed based on clinical findings. This may lead to misinterpretation, especially in the first stage of NEC, when some of the clinical symptoms may be considered as normal signs of the development of a premature infant, e.g., increased gastric residuals due to decreased motility of intestines, abdominal distention and meteorism due to feeding intolerance or the use of continuous positive airway pressure or bloody stools due to viral infection. This might be the reason for NEC hyperdiagnosis suggested by changing statistics - increasing NEC incidence, increasing the percentage medically treated NEC, reducing the percentage of surgically treated NEC, as well as reducing mortality. This means that in the clinical practice, more accurate and specific NEC criteria are required. Specific radiological findings of NEC in both of our study groups were found in $35.0 \%$ of cases, which is less common that described in other studies - where in $60.5 \%$ of cases not only pneumoperitoneum but also various other specific signs of NEC have been found (Coursey et al., 2009), making the diagnosis of NEC still based on clinical findings. Literature data shows that intestinal pneumatosis can be assessed by ultrasound earlier than by X-ray imaging and that the sensitivity of ultrasound is higher by $6.25 \%$ (Shebria et al., 2012; Eaton, 2017). There were no statistically significant difference between X-ray and ultrasound diagnostic methods between the two study groups. Our study showed that radiologically diagnosed pneumoperitoneum was reduced by $3.0 \%$ in Group 2, which confirms the decline in the perforative NEC forms.

The study showed that approximately $60 \%$ of the patients with NEC in Latvia received solely medical management. The only absolute indication of surgical treatment in case of
NEC is intestinal perforation. In both groups in CCUH NC surgical management was received by 26 to $29 \%$ of patients, similar as in clinics in United States of America, United Kingdom, Taiwan, where surgical management was done in 20 to 40 to $60 \%$ of cases (Shnabl et al., 2008; Young et al., 2009; Wu et al., 2011; Clark et Munshi, 2014). The surgical approach includes PPD, multiple stage surgeries with PPD and a following enterostomy, laparotomy with resection of ischemic bowel and creation of primary enterostomy and resection of ischemic bowel with primary anastomosis creation. The resection of ischemic bowel with primary anastomosis was first mentioned in 1979 by Kiesewetter et al. (1979) and lately this approach has been used more often due to the possibility of avoiding complications of enterostomy (e.g. prolapse, necrosis, strictures), feeding difficulties and metabolic disturbances (Hall et al., 2009). The surgical method depends on intraoperative findings - whether the necrosis of intestines is focal, multifocal or panintestinal (Hall et al., 2013). The statistically significant difference between the two groups can be explained by the decreased usage of PPD in all birth weight groups and the usage of primary anastomosis in surgical management since 2008 .

Various studies show no significant difference in mortality, days spent in hospital or late outcome in critically ill ELBW infants based on surgical approach (Raval and Moss, 2014). The mortality rate in CCUH due to NEC has decreased by $17.4 \%$, although the overall mortality still is high $(27.3 \%)$, as in USA and UK where the mortality rate differs in various NICUs and makes up 20 to $50 \%$ of cases (Maheshwari et al., 2011; Gephard et al., 2012). The decrease in mortality could be attributed to the reduction of perforated form in the second group. It is known that in cases of NEC the mortality is inversely proportional to the birth weight - mortality increases if the birth weight is below 1000 grams (Hull et al., 2014). Up to $42 \%$ of patients with NEC in CCUH were ELBW infants, and therefore the high mortality in this group of patients was associated with life-threatening underlying conditions of extremely premature infants, e.g. stage III and IV intraventricular haemorrhages, respiratory distress syndrome, hypoxic multiorgan failure, acute renal failure, disseminated intravascular coagulopathy, sepsis etc. The mortality of surgically treated NEC patients in the time period has decreased from $20 \%$ to $11 \%$ and it is lower than in the United States of America and the United Kingdom, where the mortality is $30 \%$ and $20 \%$, respectively (Hull et al., 2014; Eaton, 2017), which is associated with the critical condition of ELBW and VLBW infants in case of intestinal perforation.

\section{CONCLUSIONS}

1. The incidence of NEC in Latvia is similar to the incidence of NEC in other countries.

2. The distribution of three stages according to Bell's Staging Criteria did not differ between the study groups ( $p=$ $0.64)$. 
3. Intestinal perforations decreased by $3.0 \%$ comparatively in the NEC patients second group, although there are no statistically significant differences between radiological NEC findings between the study groups $(p=0.703)$.

4. The use of PPD, both as the sole surgical manipulation and as a multi-stage operation, was reduced in the second study group $(p=0.005)$.

5. In the second group the mortality due to NEC decreased for both medical and surgically treated infants $(p=0.003)$.

6. In both study groups the highest mortality rate was among ELBW newborns, but there was no statistically significant difference in the mortality of patients with NEC in the different weight groups between the two patient groups $(p=0.97)$.

\section{ACKNOWLEDGEMENTS}

The study was supported by the National Research Programme project Biomedicine for Public Health (BIOMEDICINE) No. 6.1 "Research on acute and chronic diseases in a wide age-range children to develop diagnostic and therapeutic algorithms to reduce mortality, prolong survival and improve quality of life”.

\section{REFERENCES}

Anonymous (2016). SSK-10 klasifikācija. Kodu tabulsaraksts un skaidrojums [International Classification of Diseases]. Available from: http://www.spkc.gov.lv/ssk10/ (accessed 03.02.2019).

Anonymous (2018). Veselības aprūpes statistika (Statistics of Health Care]. Available from:

https://www.spkc.gov.lv/lv/statistika-un-petijumi/statistika/veselibas-apr upes-statistika1 (last accessed 020.01.2019).

Bell, M. J., Ternberg, J. L., Feigin, R. D., Keating, J. P., Marshall, R., Barton, L., Brotherton, T. (1978). Neonatal necrotizing enterocolitis. Therapeutic decisions based upon clinical staging. Ann. Surg., 187 (1), 1-7.

Berman, L., Moss, R. L. (2011). Necrotizing enterocolits: An update. Semin. Fetal Neonat. Med., 16, 145-150

Christensen, R. D., Gordon, P. V., Besner, G. E. (2010). Can we cut the incidence of necrotizing enterocolitis in half - today? Fetal Pediatr Pathol., 29 (4), 185-198.

Clark, D. A., Munshi, U. K. (2014). Feeding associated neonatal necrotizing enterocolitis (Primary NEC) is an inflammatory bowel disease. Pathophysiology, 21, 29-34.

Coursey, C. A., Hollingsworth, C. L., Wriston C. et al., Beam, C., Rice, H., Bisset, G. 3rd. (2009). Radiographic predictors of disease severity in neonates and infants with necrotizing enterocolitis. Amer. J. Roentgenl., 193, 1408-1413.

Downard, C. D.., Renaud, E., St Peter, S. D., Abdullah, F., Islam, S., Saito, J. M., Blakely, M. L., Huang, E. Y., Arca, M. J., Cassidy, L., Aspelund, G., American Pediatric Surgical Association Outcomes Clinical Trials Committee (2012). Treatment of necrotizing enterocolitis: an American Pediatric Surgical Association Outcomes and Clinical Trials Committee systematic review. J. Pediatr. Surg., 47, 2111-2122.

Eaton, S. (2017). Necrotizing enterocolitis symposium: Epidemiology and early diagnosis. J. Pediatr. Surg., 52, 223-225.

Received 31 October 2018

Accepted in the final form 3 January 2019
Epelman, M., Daneman, A., Navarro, O. M., Morag, I., Moore, A. M., Kim, J. H., Faingold, R., Taylor, J., Gerstle, J. T. (2007). Necrotizing enterocolitis: Review of state-of-the-art imaging findings with pathologic correlation. Radiographics, 27, 285-305.

Gephart, S. M., Gordon, P. V., Penn, A. H., Gregory, K. E., Swanson, J. R., Maheshwari, A., Sylvester, K. (2018). Changing the paradigm of defining, detecting, and diagnosing NEC: Perspectives on Bell's stages and biomarkers for NEC. Semin Pediatr Surg., 27 (1), 3-10.

Gephart, S. M., McGrath, J. M., Effken, J. A., Halpern, M. D. (2012). Necrotizing enterocolitis risk. State of the science. Adv. Neonat. Care, 12 (2), 77-89

Gilfillan, M., Bhandari, V. (2017). Biomarkers for the diagnosis of neonatal sepsis and necrotizing enterocolitis: Clinical practice guidelines. Early Hum. Devel., 105, 25-33.

Gordon, P. V., Christensen, R., Weitkamp, J. H., Maheshwari, A. (2012). Mapping the New World of necrotizing enterocolitis (NEC): Review and opinion. J. Neonatol. Res., 2 (4), 145-172.

Gordon, P. V., Swanson, J. R., MacQueen, B. C., Christensen, R. D. (2017). A critical question for NEC researchers: Can we create a consensus definition of NEC that facilitates research progress? Semin. Perinatol., 41 (1), $7-14$.

Guner, Y. S., Chokchi, N., Petrosyan, M., Upperman, J. S., Ford, H. R., Grikscheit, T. C. (2008). Necrotizing enterocolitis — bench to bedside: Novel and emerging strategies. Semin. Pediatr. Surg., 17, 255-265.

Gupta, A., Paria, A. (2016). Etiology and medical management of NEC. Early Hum. Devel., 97, 17-23.

Hall, N. J, Eaton, S., Pierro, A. (2013). Necrotizing enterocolitis: Prevention, treatment, and outcome. J. Pediatr. Surg., 48, 2359-2367.

Hull, M. A., Fisher, J. G., Gutierrez, I. M., Jones, B. A., Kang, K. H., Kenny, M., Zurakowski, D., Modi, B. P., Horbar, J. D., Jaksic, T. (2014). Mortality and management of surgical necrotizing enterocolitis in very low birth weight neonates: A prospective cohort study. J. Amer. Coll. Surg., 218, 1148-1155.

Kim, J. H. (2014). Necrotizing enterocolitis: The road to zero. Semin. Fetal Neonat. Med., 19, 39-44.

Maheshwari, A., Corbin, L. L., Schelonka, R. L. (2011). Neonatal necrotizing enterocolitis. Res. Rep. Neonatol., 1, 39-53.

Morowitz, M. J., Poroyko, V., Caplan, M., Alverdy, J., Liu, D. C. (2010). Redefining the role of intestinal microbes in the pathogenesis of necrotizing enterocolitis. Pediatrics, 125, 777-785.

Neu, J., Walker, W. A. (2011). Medical progress. Necrotizing Enterocolitis. New Engl. J. Med., 364, 255-264.

Neu, J. (2014). Necrotizing Enterocolitis: The mystery goes on. Neonatology, 106, 289-295.

Obladen, M. (2009). Necrotizing enterocolitis - 150 years of fruitless search of the cause. Neonatology, 96, 203-210.

Raval, M. V., Moss, R. L. (2014). Current concepts in the surgical approach to necrotizing enterocolitis. Pathophysiology, 21, 105-110.

Schnabl, K. L., Van Aerde, J. E., Thomson, A. B. R., Clandinin, M. T. (2008). Necrotizing enterocolitis: A multifactorial disease with no cure. World J. Gastroenterol., 14 (14), 2142-2161.

Shebrya, N. H. Amin, S.K., Maha, A., El-Shinnawy, M. A., Imam, S. S. (2012). Abdominal ultrasonography in preterm necrotizing enterocolitis. Is it superior to plain radiography? Egypt. J. Radiol. Nucl. Med., 43, 457-463.

Torrazza, R. M., Li, N., Neu, J. (2014). Decoding the enigma of necrotising enterocolitis in premature infants. Pathophysiology, 21 (1), 21-27.

Walsh, M. C., Kliegman, R. M. (1986). Necrotising enterocolitis: Treatment based on staging criteria. Pediatr. Clin. North. Amer., 33, 179-201.

Young, C., Sharma, R., Handfield, M., Mai, V., Neu, J. (2009). Biomarkers for infants at risk for necrotizing enterocolitis: Clues to prevention? Pediatr Res., 65 (5 Pt 2), 91R-97R. 


\section{NEKROTISKĀ ENTEROKOLĪTA DIAGNOSTIKA UN ĀRSTĒŠANA JAUNDZIMUŠAJIEM LATVIJĀ}

Nekrotiskais enterokolīts (NEK) ir viens no biežākajiem saslimstības, mirstības un neatliekamās kirurğiskās palīdzības sniegšanas iemesliem neonatālajā periodā. Palielinoties l̦oti zema svara priekšlaikus dzimušo bērnu izdzīvošanai, NEK risks turpina pieaugt. Darba mērḳis bija salīdzināt NEK pacientu klīniskās un radioloğiskās pazīmes, ārstēšanas taktiku un rezultātus divos laika periodos — 2000.-2007. g. (I grupa) un 2008.-2016. g. (II grupa), kuri ārstējušies Bērnu klīniskās universitātes slimnīcas Neonatoloğijas klīnikā. Retrospektīvajā pētījumā tika iekḷauti 277 jaundzimušie ar diagnozi NEK, 105 — I grupā un 172 — II grupā. Abās pētījuma grupās nebija statistiski ticamu atšķirību NEK pacientu vidējam gestācijas vecumam un sadalījumam pēc dzimšanas svara. NEK pirmās pazīmes abās pētījuma grupās parādījās vidēji astoņas dienas pēc dzimšanas. Pielietotajām diagnostikas metodēm statistiski nozīmīgu atšķirību abās grupās nebija - aptuveni $1 / 3$ gadījumu tika konstatēta NEK specifiska radioloğiska atradne. Statistiski ticama atšḳirība starp abām pētîjuma grupām tika novērota pielietotajā terapijā un mirstībā. Konservatīva terapija abās pētījuma grupās tika pielietota $70 \%$ gadījumu. Laika gaitā samazinājās primāras peritoneālas drenāžas (PPD) veikšana: par 6,4\% — kā vienīgā ķirurğiskā manipulācija un par $8,9 \%$ PPD pielietošana ar sekojošu enterostomas izveidošanu vairāketapu operācijas ietvaros. II pētījuma grupā mirstība no NEK bija samazinājusies par 17,43\%. Ķirurğiski ārstēto mirušo pacientu skaits II grupā samazinājās par 9\%. 